\title{
Geochemical characteristics of the Slave craton lithosphere: a view from heavy mineral concentrate garnets.
}

\author{
N. Shimizu' ${ }^{1}$ N. P. Pokhilenko², and J. A. McDonald ${ }^{3}$
}

1: Department of Marine Geology and Geophysics, Woods Hole Oceanographic Institution, 360 Wood Hole Rd, Woods Hole, MA 02540-1541, USA

2: United Institute for Geophysics and Mineralogy, Russian Academy of Science, Novosibirsk, Russia

3: Winspear Resources, Ltd.

Chemical characteristics of lithospheric peridotites and constituent minerals could reflect processes of lithosphere formation and evolution. The recognition that the Kaapvaal and Siberian lithospheric peridotites have excessive abundances of orthopyroxene (e.g., Boyd, 1996) has important implications for geochemical processes and environments in which cratonic roots in these regons occurred (e.g., Kelemen and Hart, 1995). Ancient "enrichment process" inferred from Sm-Nd model ages (e.g., Richardson et al., 1978; Pearson et al., 1995) may be related to processes of orthopyroxene formation.

In contrast, recent results show that lithospheric peridotites from the Slave craton(Canada) do not have excessive orthopyroxene (Boyd, 1997), indicating that evolutionary histories could vary from craton to craton.

An attempt was made here to examine whether trace element abundance patterns of lithospheric peridotites beneath the Slave craton reflect the differences in mineralogy and the major element composition. Since only very few peridotite xenoliths have been available for examination, garnet grains in heavy mineral concentrates collected for diamond exploration in the Slave Province were analyzed here as representing random samples of the lithospheric root beneath the Canadian Shield.

An epoxy mount containing more than 450 grains from the Camsell Lake kimberlite field (CL 60493) was analyzed for major elements (at UIGGM, Novosibirsk) and for $\mathrm{La}, \mathrm{Ce}, \mathrm{Nd}, \mathrm{Sm}, \mathrm{Eu}, \mathrm{Dy}$, $\mathrm{Er}, \mathrm{Yb}, \mathrm{Ti}, \mathrm{V}, \mathrm{Sr}, \mathrm{Y}$, and $\mathrm{Zr}$ (at Woods Hole Oceanographic Institution using a Cameca IMS $3 \mathrm{f}$ ion probe). For all elements an energy offset of $-90 \mathrm{v}$ was used. Analytical uncertainties range from $10-$ $30 \%$ for REE to $3-5 \%$ for other trace elements.

Results on garnets from the CL-25 kimberlite pipe from the same general area (Pokhilenko et al., 1997) demonstrate that $\mathrm{CaO}$ vs $\mathrm{Cr} 2 \mathrm{O} 3$ variations of the Slave craton garnets are significantly different from those of a similar population (heavy mineral concentrate garnets) from the Udachnaya pipe (Sobolev et al., 1977; see their Fig. b). The Slave population studied here is characterized by relative scarcity of subcalcic "harzburgite" compositions ( $<4 \%$ of 320 analyzed; cf. $\sim 20 \%$ of 265 for Udachnaya), and by dominant "lherzolitic" compositions (>90\%). It is also noticeable that garnets with high $\mathrm{CaO}$ and $\mathrm{Cr} 2 \mathrm{O} 3(\mathrm{CaO}>6 \%, \mathrm{Cr} 2 \mathrm{O} 3>10 \%)$ are present ( $\sim 8 \%$; $\mathrm{cf} \sim 6 \%$ for Udachnaya).

Salient points of the trace element results can be summarized as follows:

(1) Sinusoidal REE patterns, which are typical for purple/pink garnets from Kaapvaal and Siberian peridotites, are not common in the Slave craton lherzolitic garnets $(<20 \%)$;

(2) Instead, the majority of lherzolitic garnets have smoothly LREE-depleted patterns typical for mantle garnets with [La]n $\sim 0.1$ and [Yb]n $\sim 10$.

(3) High-Ca, high-Cr garnets invariably show LREE-enriched and sinusoidal patterns, and can have anomalously high $\mathrm{Sr}$ contents (>10 ppm).

The results demonstrate that trace element abundances of lithospheric peridotites beneath the Slave craton rarely display evidence for "metasomatism" and "enriched signatures". This could 
be a reflection of their differences in major elements and orthopyroxene abundances from the Kaapvaal and Siberian counterparts.

\section{References}

Boyd, F. R., 1989, Compositional distinction between oceanic and cratonic lithosphere: Earth and Planetary Science Letters, v. 96, p. 15-26.

Boyd, F. R., Pokhinlenko, N. P., Pearson, D. G., and Mertzman, S. A., 1997, Composition of the Siberian cratonic mantle: Evidence from Udachynaya peridotite xenoliths: Contributions to Mineralogy and Petrology, in press.

Kelemen, P. B., and Hart, S. R., 1996, Silica enrichment in the continental lithosphere via melt/rock reaction: V. M. Goldchmidt Conference Abstract, p. 308.

Kelemen, P. B., Hart, S. R., and Bernstein, S., 1998, Silica enrichment in the continental lithosphere via melt/rock reaction: Earth and Planetary Science Letters, in press.

Pearson, D. G., Shirey, S. B., Carlson, R. W., Boyd, F. R., Pokhilenko, N. P., and Shimizu, N., 1995, Re-Os, Sr-Nd, and Rb-Sr isotope evidence for thick archean lithospheric mantle beneath the Siberian Craton modified by multistage metasomatism: Geochimica et Cosmochimica Acta, v. 59, p. 959-977.

Pokhilenko, N. P., McDonald, J. A., Melnick, U., McCorquodale, J., Reimers, L. F., and Sobolev, N. V., 1997, Indicator minerals from the CL-25 kimberlite pipe, Slave craton, Northwest Territories, Canada: Russ. Geol. Geophys., v. 38, p. 550-558.

Richardson, S. H., Erlank, A. J., and Hart, S. R., 1985, Kimberlite-borne garnet peridotite xenoliths from old enriched subcontinental lithosphere: Earth and Planetary Science Letters, v. 75, p. 116-128. Sobolev, N. V., Pokhilenko, N. P., Larent'ev, Y. G., and Yefimova, E. S., 1977, Deep-seated xenoliths, xenocrysts in kimberlite and crystalline inclusions in diamonds from "Udachinaya" kimberlite pipe, Yakutia: Extended Abstract Kimberlite Conference, Santa Fe. 